Article

\title{
Direct Solid Oxide Electrolysis of Carbon Dioxide: Analysis of Performance and Processes
}

\author{
Severin Foit ${ }^{1,+}\left(\mathbb{D}\right.$, Lucy Dittrich ${ }^{1,2,+}$, Tobias Duyster ${ }^{1}\left(\mathbb{D}\right.$, Izaak Vinke ${ }^{1}$, Rüdiger-A. Eichel ${ }^{1,2}(\mathbb{D}$ \\ and L. G. J. (Bert) de Haart $1, *(\mathbb{D})$ \\ 1 Institute of Energy and Climate Research, Fundamental Electrochemistry (IEK-9), Forschungszentrum Jülich \\ GmbH, 52425 Jülich, Germany; s.foit@fz-juelich.de (S.F.); 1.dittrich@fz-juelich.de (L.D.); \\ t.duyster@fz-juelich.de (T.D.); i.c.vinke@fz-juelich.de (I.V.); r.eichel@fz-juelich.de (R.-A.E.) \\ 2 Institute of Physical Chemistry, RWTH Aachen University, 52074 Aachen, Germany \\ * Correspondence: 1.g.j.de.haart@fz-juelich.de \\ + Authors with equal contribution.
}

Received: 1 October 2020; Accepted: 26 October 2020; Published: 31 October 2020

\begin{abstract}
Chemical industries rely heavily on fossil resources for the production of carbon-based chemicals. A possible transformation towards sustainability is the usage of carbon dioxide as a source of carbon. Carbon dioxide is activated for follow-up reactions by its conversion to carbon monoxide. This can be accomplished by electrochemical reduction in solid oxide cells. In this work, we investigate the process performance of the direct high-temperature $\mathrm{CO}_{2}$ electrolysis by current-voltage characteristics (iV) and Electrochemical Impedance Spectroscopy (EIS) experiments. Variations of the operation parameters temperature, load, fuel utilization, feed gas ratio and flow rate show the versatility of the procedure with maintaining high current densities of 0.75 up to $1.5 \mathrm{~A} \cdot \mathrm{cm}^{-2}$, therefore resulting in high conversion rates. The potential of the high-temperature carbon dioxide electrolysis as a suitable enabler for the activation of $\mathrm{CO}_{2}$ as a chemical feedstock is therefore appointed and shown.
\end{abstract}

Keywords: carbon dioxide; solid oxide electrolysis; carbon dioxide utilization; $\mathrm{CO}_{2}$-electrolysis; high-temperature electrolysis; carbon dioxide reduction

\section{Introduction}

The world-wide chemical industry is currently depending on fossil resources for the production of carbon based chemicals. To reach full sustainability in the sector of chemical industry, the necessity of circular carbon economy is evident. This is not possible by exploiting fossil resources. An abundant compound containing carbon is carbon dioxide $\left(\mathrm{CO}_{2}\right)$. Even in a scenario of $100 \%$ renewable energy generation, emissions of carbon dioxide by processes within the chemical sector is in the range of multiple hundred million metric megatons per year [1]. As $\mathrm{CO}_{2}$ has a low energetic value and is therefore rather inert, it has to be activated to be used as a starting material in value-chains of the chemical industry. Carbon monoxide (CO) is already a bulk chemical in industrial chemistry. It is used as a building block in polymers like e.g., polyurethanes and polycarbonates, but can also be transformed to a vast range of products as the carbon containing part in syngas, a mixture of carbon monoxide and hydrogen [2-7]. Hence, a sustainable conversion of carbon dioxide to carbon monoxide is enabling the processes of carbon capture and utilization (CCU) and power-to-x [8].

Using renewable energy, the electrochemical reduction of $\mathrm{CO}_{2}$ to $\mathrm{CO}$ is an interesting and seemingly simple process for the solution of the above mentioned challenges. This reaction has been examined both for low-temperature and high-temperature procedures with vast differences in performance, efficiencies and general operation parameters [9]. The high-temperature electrolysis of 
$\mathrm{CO}_{2}$ to $\mathrm{CO}$ on ceramic solid oxide cells seems superior in these regards with a faradaic efficiency of $100 \%$ and overall energetic efficiencies of over $75 \%$. This conversion has been attempted mostly as a part of syngas production by using water and carbon dioxide simultaneously as starting feeds [10], which is not a direct electrolysis of carbon dioxide in particular. Concerning the electrolysis of pure carbon dioxide, a few aspects have been viewed at, however with a focus on materials [11-18]. We present the process investigation of the variation of different operation parameters temperature, load, fuel utilization, feed gas ratios and flow rates of the high-temperature solid oxide electrolysis of carbon dioxide to carbon monoxide.

\section{Materials and Methods}

The commercially available single button cells (Elcogen $\AA$, Tallinn, Estonia) used in the following experiments consist of a cathode-supported porous NiO-8YSZ-cermet fuel cathode, a $8 \%$-Yttria-stabilized zirconia (8YSZ) electrolyte, a Gadolinium-doped ceria (GDC) and a porous $\mathrm{La}_{0.6} \mathrm{Sr}_{0.4} \mathrm{CoO}_{3-\delta}$ (LSC) oxygen anode. The cathode, electrolyte and GDC layer have a diameter of $20 \mathrm{~mm}$ and a totalled thickness of $300 \pm 30 \mu \mathrm{m}$. The anode has a diameter of $10 \mathrm{~mm}$ and a thickness of $15 \pm 5 \mu \mathrm{m}$, giving an active area of $0.79 \mathrm{~cm}^{2}$

The single-cells are installed in a two-electrode conductivity \& impedance spectroscopy Probostat-setup (Norwegian Electro Cermaics ${ }^{\circledR}$ NORECS, Oslo, Norway). A gold ring is used as a sealing sample between the anodic side of the cell and the inner ceramic gas chamber to separate the air and fuel side. The current collector on the fuel side consists of a nickel and a platinum mesh. On the air side, only platinum is used for the current collection. The setup is enclosed and heated up with a furnace from the company Carbolite Gero®(Neuhausen, Germany). The heating rate is kept at $2{ }^{\circ} \mathrm{C} \cdot \mathrm{min}^{-1}$ throughout all the measurements to protect the materials from thermomechanical stress. The reduction of the fuel electrode from NiO-YSZ to Ni-YSZ to activate the catalyst properties of Nickel is carried out at $900{ }^{\circ} \mathrm{C}$ with a stepwise increase of hydrogen concentration in the fuel feed gas starting at $0 \%$ up to $100 \%$ with nitrogen as balance gas.

In this work, we have chosen the temperatures 800 and $850{ }^{\circ} \mathrm{C}$ for the investigation of effects of variating operation parameters. This is a suitable compromise, by which cell performance and material stability can be guaranteed. Besides, a temperature series between $700-900^{\circ} \mathrm{C}$ in equivalent $\mathrm{T}^{-1} / \mathrm{K}^{-1}$-steps with the volumetric fuel composition of $80: 20$ of $\mathrm{CO}_{2}: \mathrm{CO}$ has been performed to apply the Arrhenius equation.

The supply of the gases $\mathrm{H}_{2}, \mathrm{~N}_{2}, \mathrm{CO}_{2}, \mathrm{CO}$ (fuel side) and air (air side) is controlled by mass flow controllers (MFC, Bronkhorst Nord $囚$, Kamen, Germany). A constant volume flow of $6 \mathrm{~L} \cdot \mathrm{h}^{-1}$ is applied to both gas chambers, when not specified differently. Current-voltage characteristics (iV) and Electrochemical Impedance Spectroscopy (EIS) experiments are managed via a Vertex 5A Potentiostat/Galvanostat (Ivium Technologies $₫$, Eindhoven, Netherlands) using a two-electrode system. The cell performance is measured consecutively twice by applying a differential current with a scan rate of $10 \mathrm{~mA} \cdot \mathrm{s}^{-1}$ from open cell voltage (OCV) up to $1.4 \mathrm{~V}$. The area-specific resistance (ASR) is calculated using the numerical differential of the $\mathrm{iV}$ curves at $\mathrm{OCV}$ and $350 \mathrm{~mA} \cdot \mathrm{cm}^{-1}$.

The process analysis of the cell is determined by AC characterization at OCV and $350 \mathrm{~mA} \cdot \mathrm{cm}^{-2}$. The spectra are recorded in a frequency range from $110 \mathrm{kHz}$ to $0.11 \mathrm{~Hz}$ with 73 measuring points and an applied amplitude of $20 \mathrm{~mA}$.

\section{Results}

\subsection{Performance}

The performance of high-temperature $\mathrm{CO}_{2}$-electrolysis was studied by dc current-voltage measurements. The resulting $\mathrm{iV}$ curves for various $\mathrm{CO}_{2}$ partial pressures, temperatures and flow rates are shown in Figure 1a-c, respectively. 


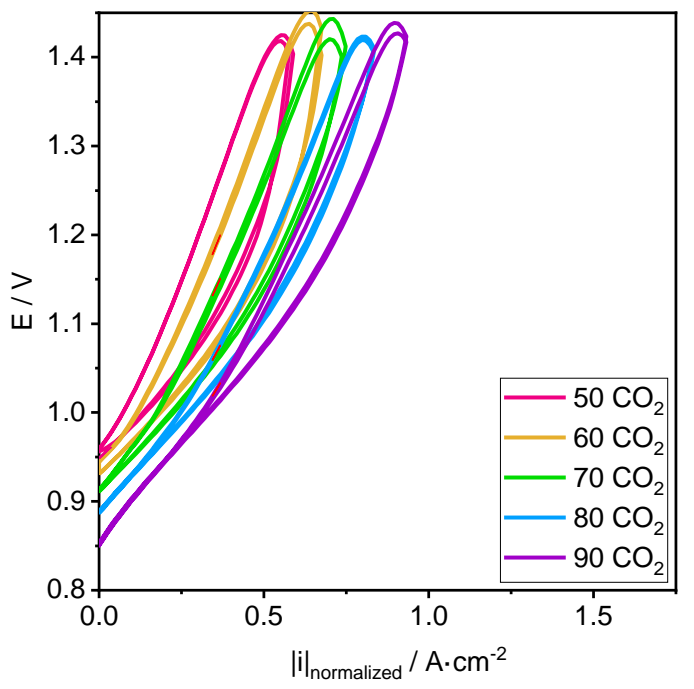

(a)

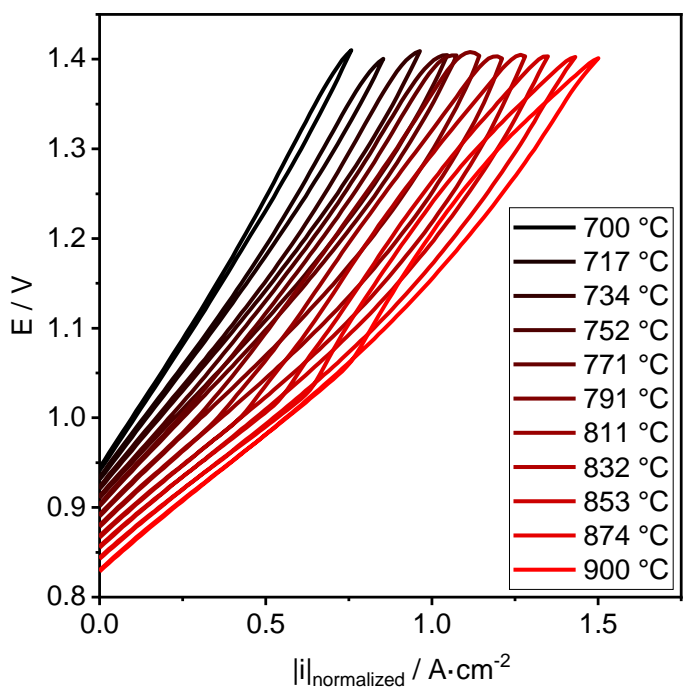

(b)

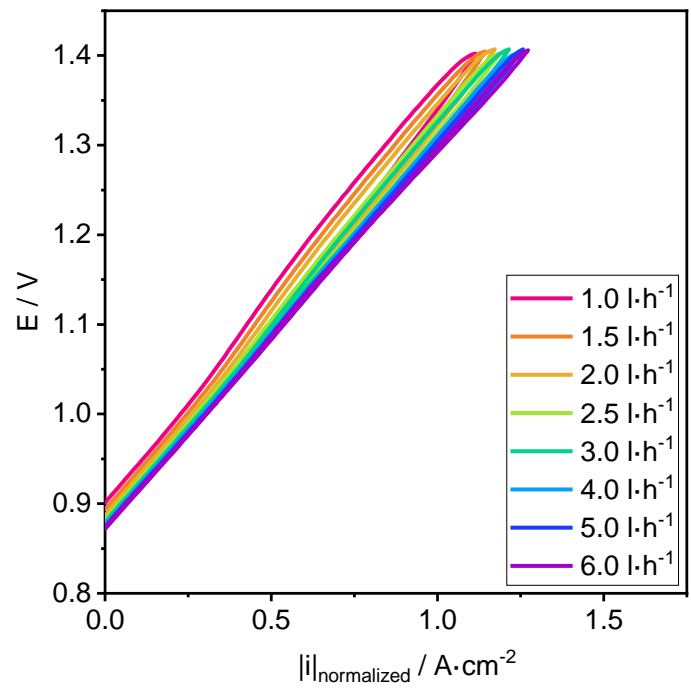

(c)

Figure 1. iV curves at various operating parameters: (a) variation of $\mathrm{CO}_{2}: \mathrm{CO}$ ratio at $800{ }^{\circ} \mathrm{C}$ and 6 $\mathrm{L} \cdot \mathrm{h}^{-1} ;(\mathbf{b})$ variation of temperature for a ratio of $\mathrm{CO}_{2}: \mathrm{CO}$ of $80: 20$ at $6 \mathrm{~L} \cdot \mathrm{h}^{-1} ;(\mathbf{c})$ variation of flow rate for a ratio of $\mathrm{CO}_{2}: \mathrm{CO}$ of $80: 20$ at $800{ }^{\circ} \mathrm{C}$.

The variation of $\mathrm{CO}_{2}$ partial pressure was balanced by $\mathrm{CO}$. That means reducing $\mathrm{CO}_{2}$ partial pressure was accompanied by increasing $\mathrm{CO}$ and vice versa. The obtained area specific resistances (ASR) and current densities at $1.4 \mathrm{~V}\left(\mathrm{i}_{1.4} \mathrm{~V}\right)$ for variation of $\mathrm{CO}_{2}$ partial pressure are presented in Figure 2a (values in Table A1 in Appendix A). For increasing the $\mathrm{CO}_{2}$ partial pressure, the ASR at OCV increases with a factor of 1.6 from $0.34 \Omega \cdot \mathrm{cm}^{2}$ at $50 \% \mathrm{CO}_{2}$ to $0.56 \Omega \cdot \mathrm{cm}^{2}$ at $90 \% \mathrm{CO}_{2}$. The increase in ASR also increased with each $10 \%$ step of $\mathrm{CO}_{2}$ partial pressure. From $50 \%$ to $60 \%$ it only increases by $0.02 \Omega \cdot \mathrm{cm}^{2}$, while from $80 \%$ to $90 \%$ the increase is $0.13 \Omega \cdot \mathrm{cm}^{2}$. At $0.35 \mathrm{~A} \cdot \mathrm{cm}^{-2}$, however, the trend is opposite of the one observed at OCV. With increasing the $\mathrm{CO}_{2}$ partial pressure, the ASR decreases. Analog to before, there is a factor of 1.6, only this time from $0.42 \Omega \cdot \mathrm{cm}^{2}$ at $90 \% \mathrm{CO}_{2}$ to $0.67 \Omega \cdot \mathrm{cm}^{2}$ at $50 \% \mathrm{CO}_{2}$. The current density at $1.4 \mathrm{~V}$ increases with increasing $\mathrm{CO}_{2}: \mathrm{CO}$ ratio with a very similar increase of 0.08 or $0.09 \mathrm{~A} \cdot \mathrm{cm}^{-2}$ for each 10 percentage point step of partial pressure. The experimentally determined OCV is comparable to the theoretical OCV, which is calculated by the Nernst equation. Deviations are up to $1 \%$. 


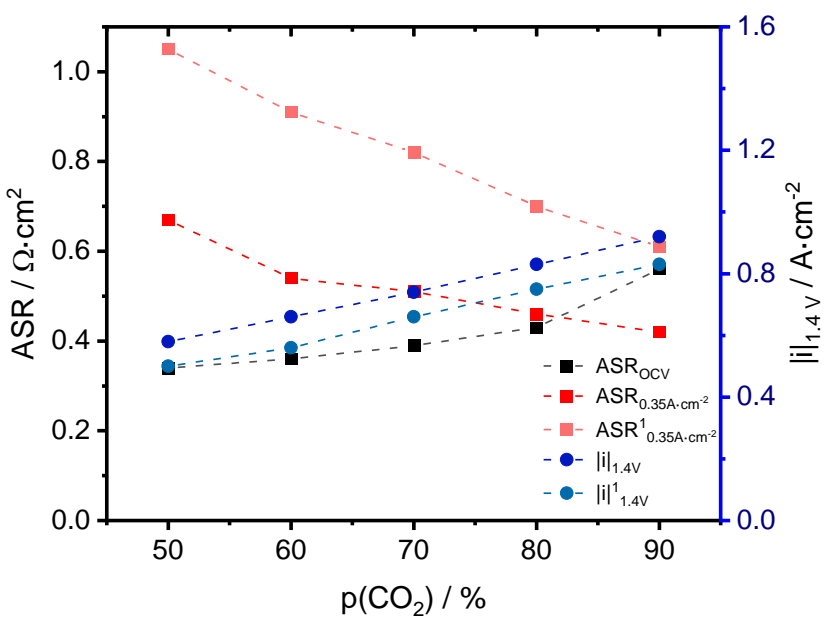

(a)

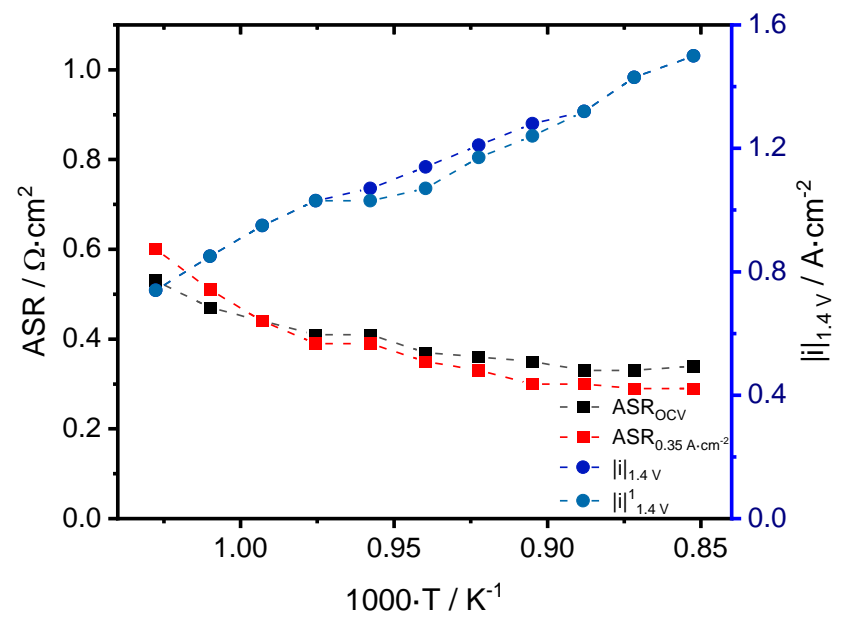

(b)

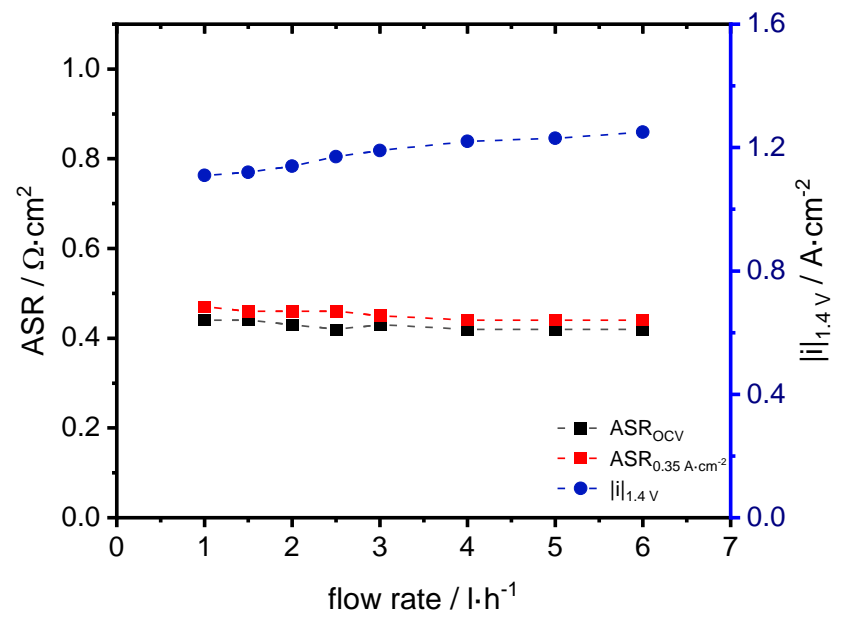

(c)

Figure 2. (a) ASR, $|i| 1.4 \mathrm{~V}$ and $\mathrm{OCV}$ for various ratios of $\mathrm{CO}_{2}: \mathrm{CO}$ at $800^{\circ} \mathrm{C}$. (b) ASR, $|i| 1.4 \mathrm{~V}$ and OCV for various temperatures for the ratio of $\mathrm{CO}_{2}: \mathrm{CO}$ of 80:20. (c) ASR, $|i| 1.4 \mathrm{~V}$ and OCV for varied flow rate for a $\mathrm{CO}_{2}: \mathrm{CO}$ ratio of 80:20 at $800{ }^{\circ} \mathrm{C}$. ${ }^{1}$ Two values are given because of the hysteresis. The first denotes the forward scan and the second the backward scan of the $\mathrm{iV}$ curve. 
The variation of temperature was performed at a gas composition of $80 \% \mathrm{CO}_{2}+20 \% \mathrm{CO}$ at temperatures in the range of $700-900^{\circ} \mathrm{C}$. The respective ASRs and $\mathrm{i}_{1.4 \mathrm{~V}}$ are given in Figure $2 \mathrm{~b}$ (values in Table A2) showing decreased ASR and increased $\mathrm{i}_{1.4 \mathrm{~V}}$ with increased temperature. The decrease in ASR is steeper at OCV than at $0.35 \mathrm{~A} \cdot \mathrm{cm}^{-2}$. Moreover, the ASR increases at $700{ }^{\circ} \mathrm{C}$ going from $\mathrm{OCV}$ to $0.35 \mathrm{~A} \cdot \mathrm{cm}^{-2}$, while it decreases at $900{ }^{\circ} \mathrm{C}$. The transition from this increase to decrease is at around $734{ }^{\circ} \mathrm{C}$, where both values of ASR are the same. The OCV follows the trend given by the Nernst equation and decreases with increasing temperature.

For an investigation of the residence time, flow rates were varied in the range of 1-6 L $\cdot \mathrm{h}^{-1}$. The obtained ASRs do not vary significantly, while the current density at $1.4 \mathrm{~V}$ increases by $0.14 \mathrm{~A} \cdot \mathrm{cm}^{-2}$ with increasing the flow rate from $1 \mathrm{~L} \cdot \mathrm{h}^{-1}$ to $6 \mathrm{~L} \cdot \mathrm{h}^{-1}$ (Figure 2c, Table A3). For the OCV it can be observed that for flow rates below $3 \mathrm{~L} \cdot \mathrm{h}^{-1}$ the initial OCV and the one measured after an $\mathrm{IV}$ curve cycle increasingly differ. At $3 \mathrm{~L} \cdot \mathrm{h}^{-1}$ the difference is only $10 \mathrm{mV}$. However, at $1 \mathrm{~L} \cdot \mathrm{h}^{-1}$ it is already a deviation of $30 \mathrm{mV}$.

\subsection{Impedance Analysis}

Electrochemical impedance spectra were taken for the same parameter variations as discussed for the performance analysis. Additionally, the comparison at variation of current is performed. The spectra at various current densities, $\mathrm{CO}_{2}: \mathrm{CO}$ ratios, temperatures and flow rates are shown in Figure $3 a-d$, respectively.

The variation of current density in Figure 3 a shows increased total resistance at $700{ }^{\circ} \mathrm{C}$ resulting from a huge increase in high and middle frequency processes. At $900{ }^{\circ} \mathrm{C}$ the total resistance is first decreasing with current and starts increasing at about $0.35 \mathrm{~A} \cdot \mathrm{cm}^{-2}$. Compared to the spectra at $700{ }^{\circ} \mathrm{C}$ the increase in resistance is mainly caused by low frequency impedance contributions. In both cases the ohmic resistance is constant over the whole current density range. Especially the low frequency process is shifted to lower frequencies with increased current density causing the semicircle to be pushed out of the measurement range and only showing half of it in the spectra.

The $\mathrm{CO}_{2}: \mathrm{CO}$ ratio causes different trends at $\mathrm{OCV}$ and $0.35 \mathrm{~A} \cdot \mathrm{cm}^{-2}$ as can be seen in Figure $3 \mathrm{~b}$. At $\mathrm{OCV}$ the total resistance increases strongly with increasing the $\mathrm{CO}_{2}: \mathrm{CO}$ ratio. The major contribution is from the low frequency impedance parts. At $0.35 \mathrm{~A} \cdot \mathrm{cm}^{-2}$ the trend is opposite: an increased $\mathrm{CO}_{2}: \mathrm{CO}$ ratio causes the impedance to decrease. In this case, the ratio also influences the middle frequency region of the impedance. With increased $\mathrm{CO}_{2}: \mathrm{CO}$ ratio the low frequency process is also shifted towards higher frequencies and more into the measured frequency range.

The variation of temperature in Figure $3 c$ is the first measurement to also influence the ohmic resistance. With increased temperature it is decreasing. Similarly, the polarization resistance is decreasing with increased temperature. The main contributions are from the high and middle frequency impedances. The low frequency process is shifted as well with variation of temperature. Higher temperatures shift it to higher frequencies and into the measurement range.

The last process parameter that was investigated by impedance spectroscopy is the flow rate. Here, the behavior is again different at OCV compared to $0.35 \mathrm{~A} \cdot \mathrm{cm}^{-2}$. At OCV the flow rate shows no significant influence on the spectra, while at $0.35 \mathrm{~A} \cdot \mathrm{cm}^{-2}$ a slight decrease of middle and low frequency impedance can be observed for increased flow rate. 

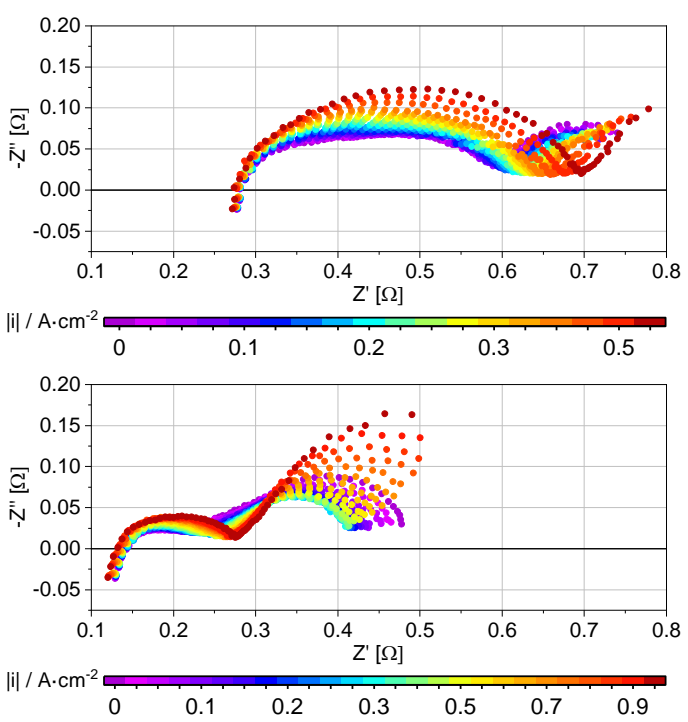

(a)

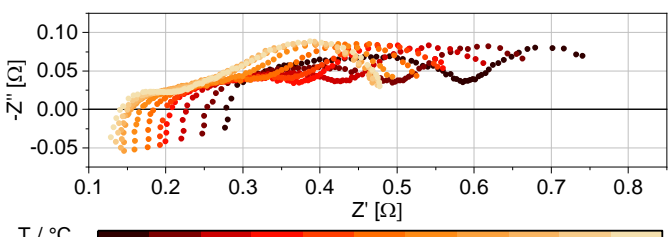

700717734752771791811832853874901

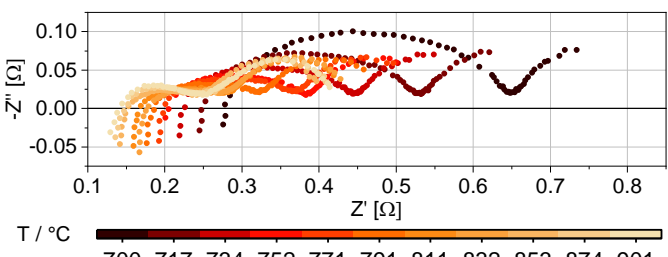

700717734752771791811832853874901

(c)
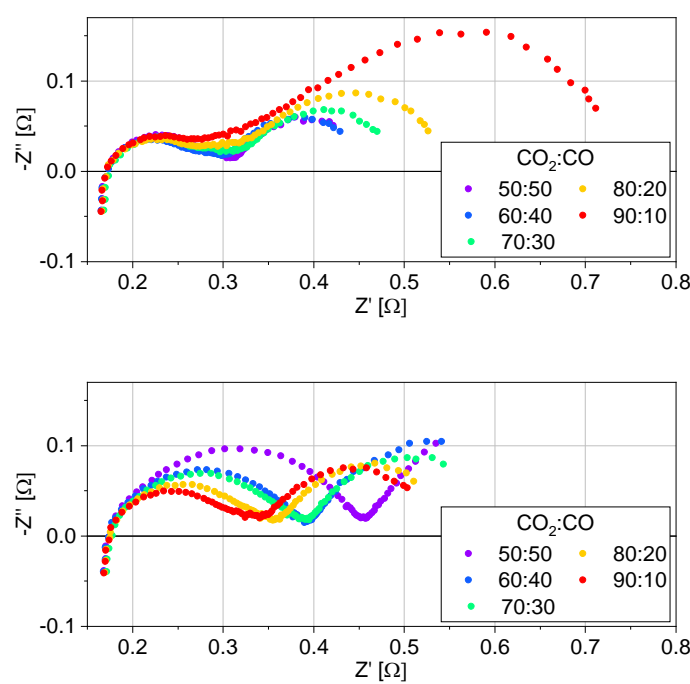

(b)
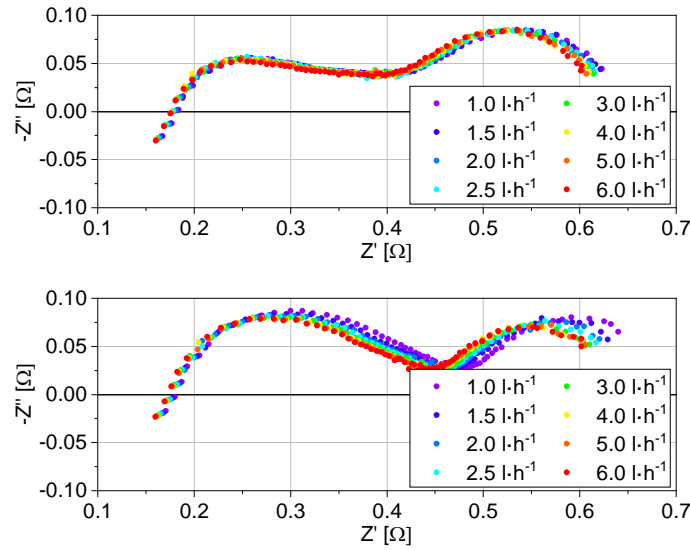

(d)

Figure 3. EIS spectra at various operating parameters: (a) variation of current density for a ratio of $\mathrm{CO}_{2}: \mathrm{CO}$ of $80: 20$ at $6 \mathrm{~L} \cdot \mathrm{h}^{-1}$ at $700{ }^{\circ} \mathrm{C}$ (top) and $900{ }^{\circ} \mathrm{C}$ (bottom); (b) variation of $\mathrm{CO}_{2}: \mathrm{CO}$ ratio at $800{ }^{\circ} \mathrm{C}$ and $6 \mathrm{~L} \cdot \mathrm{h}^{-1}$ at $\mathrm{OCV}$ (top) and $0.35 \mathrm{~A} \cdot \mathrm{cm}^{-2}$ (bottom); (c) variation of temperature for a ratio of $\mathrm{CO}_{2}: \mathrm{CO}$ of 80:20 at $6 \mathrm{~L} \cdot \mathrm{h}^{-1}$ at OCV (top) and $0.35 \mathrm{~A} \cdot \mathrm{cm}^{-2}$ (bottom); (d) variation of flow rate for a ratio of $\mathrm{CO}_{2}: \mathrm{CO}$ of $80: 20$ at $800{ }^{\circ} \mathrm{C}$ at $\mathrm{OCV}$ (top) and $0.35 \mathrm{~A} \cdot \mathrm{cm}^{-2}$ (bottom).

\section{Discussion}

\subsection{Performance}

The electrolysis performance can be defined as the amount of product produced per time unit. This is given by the current or current density as the current defines the absolute converted amount of reactant per second according to Faraday's law. For a high performance the current density should be as high as possible.

As can be seen from the iV curves in Figure 1, the current density generally increases with increasing the voltage. However, increasing the voltage above $1.4 \mathrm{~V}$ leads to severe and fast degradation according to literature [3] and our own previous studies. Compared to the experiments reaching up to $1.5 \mathrm{~A} \cdot \mathrm{cm}{ }^{-2}$ at $1.4 \mathrm{~V}$ seen in Figure 1, experiments going up to $1.8 \mathrm{~V}$ (even for as short as $15 \mathrm{~min}$ ), the correspondent current density at $1.4 \mathrm{~V}$ was permanently reduced to below $0.1 \mathrm{~A} \cdot \mathrm{cm}^{-2}$. As measure for the performance it is therefore the current density at $1.4 \mathrm{~V}$ that is compared. 
However, due to the non-linearity at higher current density caused by transport limitations it might be more suitable to perform the electrolysis at lower voltages, as the benefit of higher currents do not justify the increased power input.

Another measure for the performance of a cell is the area specific resistance, which is a measure for the energy loss of the system. It includes the loss from multiple processes, which can be deconvoluted in impedance spectroscopy.

The analysis of the performance at different process parameters show the highest performance concerning the current density at $1.4 \mathrm{~V}$ for $90 \% \mathrm{CO}_{2}+10 \% \mathrm{CO}, 900{ }^{\circ} \mathrm{C}$ and a flow rate of $6 \mathrm{~L} \cdot \mathrm{h}^{-1}$. Reducing the amount of $\mathrm{CO}_{2}$ results in less available reactant and this leads to earlier mass transport limitations. The limitations occur mostly at higher currents when not enough reactant can be transported to the cell for the conversion forced by the current to take place. The potential increases often abruptly at a limiting current density. Regarding the fuel utilization, however, it can be seen that it does not even reach $10 \%$ for $50 \% \mathrm{CO}_{2}$. Only by decreasing the flow rate the utilization can be increased up to $40 \%$ (Figure 4). It must be noted though that the two measurements were conducted on different cells and it seems they show different grades of degradation. The degradation may hinder the diffusion pathways through the cell, reducing the local concentration of reactant. This explains the limiting current already at such low overall utilizations.

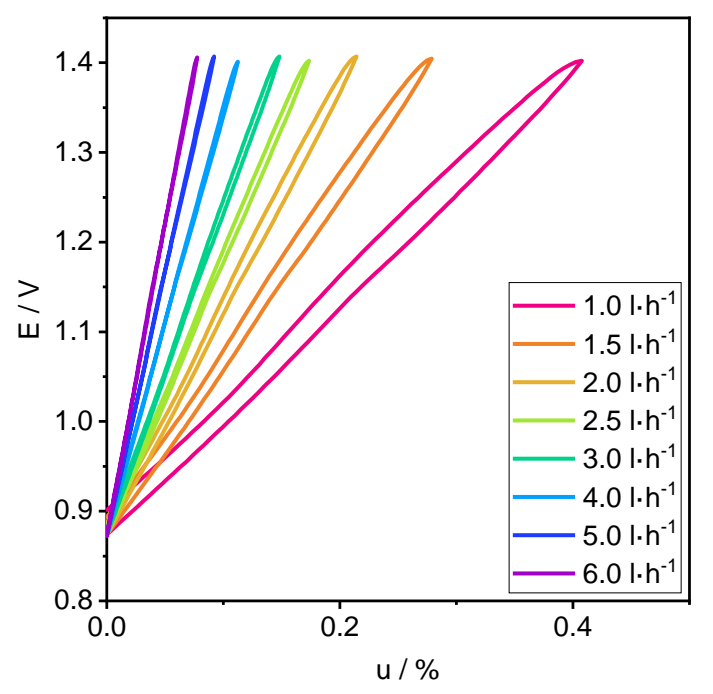

Figure 4. Operating potential dependent on the fuel utilization, calculated according to Faraday, for various flow rates for a composition of $80 \% \mathrm{CO}_{2}+20 \% \mathrm{CO}$ at $800{ }^{\circ} \mathrm{C}$.

The comparison of ASR at OCV and $0.35 \mathrm{~A} \cdot \mathrm{cm}^{-2}$ showed an increase from OCV to $0.35 \mathrm{~A} \cdot \mathrm{cm}^{-2}$ for $\mathrm{CO}_{2}$ concentrations of $80 \%$ and lower. For a concentration of $90 \% \mathrm{CO}_{2}$, however the ASR decreases. Observing a larger ASR at OCV than under load is typical for a pronounced activation overpotential, which is especially dominant at low currents. Another explanation for the behavior at low current density is the Nernst potential. As $90 \% \mathrm{CO}_{2}+10 \% \mathrm{CO}$ is in the boundary of the Nernst potential, a decrease in $\mathrm{CO}_{2}$ and increase in $\mathrm{CO}$, like it will happen during electrolysis, causes the Nernst potential to increase steep in the range of $90 \% \mathrm{CO}_{2}$ down to $80 \% \mathrm{CO}_{2}$. Below $80 \% \mathrm{CO}_{2}$, the increase is significantly lower. The small changes in $\mathrm{CO}_{2}: \mathrm{CO}$ ratio during electrolysis will then cause the thermodynamic voltage to increase much more at $90 \% \mathrm{CO}_{2}$ in the feed than at $50 \% \mathrm{CO}_{2}$.

Varying the temperature shows a similar influence on the ASR comparing OCV to $0.35 \mathrm{~A} \cdot \mathrm{cm}^{-2}$. Here the transition is already at around $734{ }^{\circ} \mathrm{C}$. The deviation observed at around $800{ }^{\circ} \mathrm{C}$ in this experiment may be explained by the use of a different cell than for the composition measurement. It also indicates that probably both an activation overpotential and the Nernst potential are causing this decrease in ASR at low current densities. 
The temperature dependence measurement is also performed to gain information on the activation energies of the processes. Figure 5 shows the Arrhenius representation of the ASR $\mathrm{OCV}$. It can be observed that for temperatures above $850{ }^{\circ} \mathrm{C}$ the ASR remains constant. Below $850{ }^{\circ} \mathrm{C}$ the logarithmic of the resistance shows a slightly curved trend with recursive temperature increase. The ASR includes all the underlying processes that may occur during electrolysis. Seeing a slightly curved Arrhenius behavior indicates the domination of different processes at lower temperatures than at higher temperatures. Additionally, it may indicate an increasing degradation with increased temperature. The series was conducted from low to high temperatures increasing the operation time of the cell with each temperature step. Especially the constant resistance above $850{ }^{\circ} \mathrm{C}$ is attributed to degradation as the LSC material of the anode is reported to be unstable above this temperature [19].

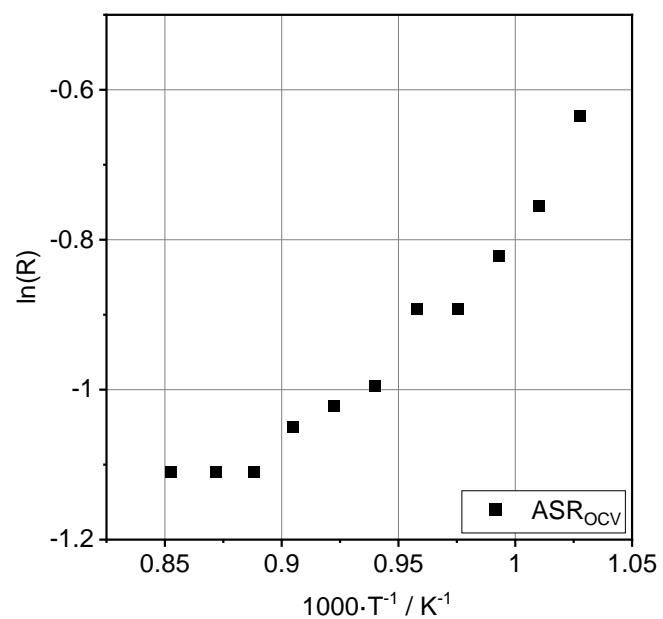

Figure 5. Arrhenius representation $\left(\ln (\mathrm{R}) \rightarrow \mathrm{T}^{-1}\right)$ of the area specific resistance for a ratio of $\mathrm{CO}_{2}: \mathrm{CO}$ of $80: 20$.

\subsection{Process Analysis}

The impedance spectra in Figure 3 were analyzed by an equivalent circuit model (ECM) containing an inductance, a serial resistance and four RQ elements (a resistor and constant-phase element in parallel). The obtained resistances are plotted against their respective varied parameter in Figures 6-9.

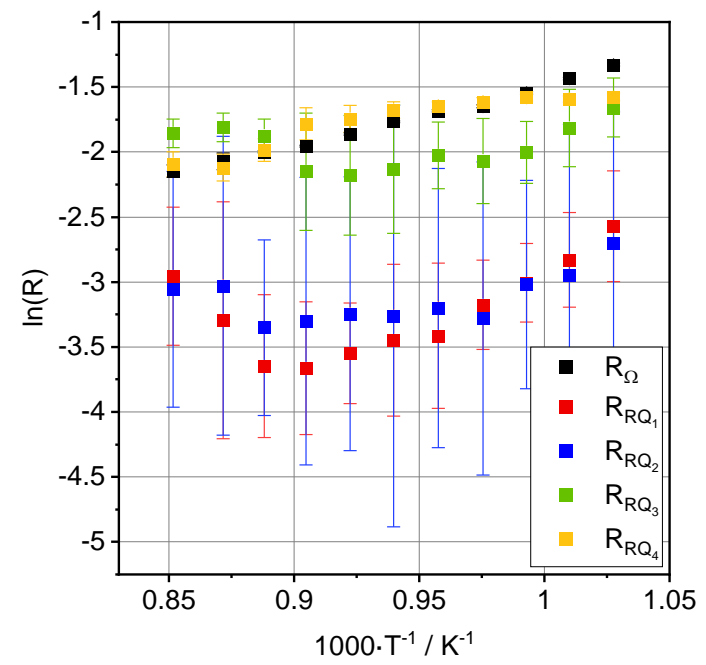

(a)

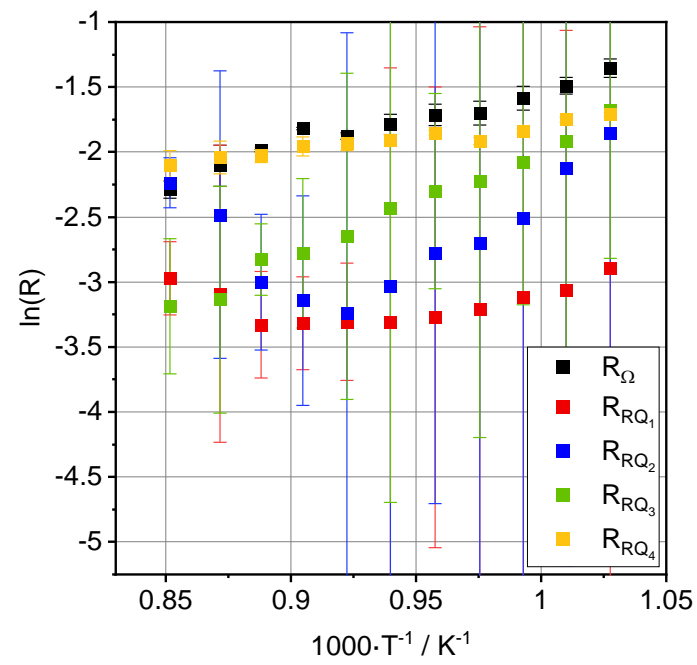

(b)

Figure 6. Arrhenius plot for the resistances for a ratio of $\mathrm{CO}_{2}: \mathrm{CO}$ of $80: 20$ at $6 \mathrm{~L} \cdot \mathrm{h}^{-1}$ at $(\mathbf{a}) \mathrm{OCV}$ and (b) $0.35 \mathrm{~A} \cdot \mathrm{cm}^{-2}$. 


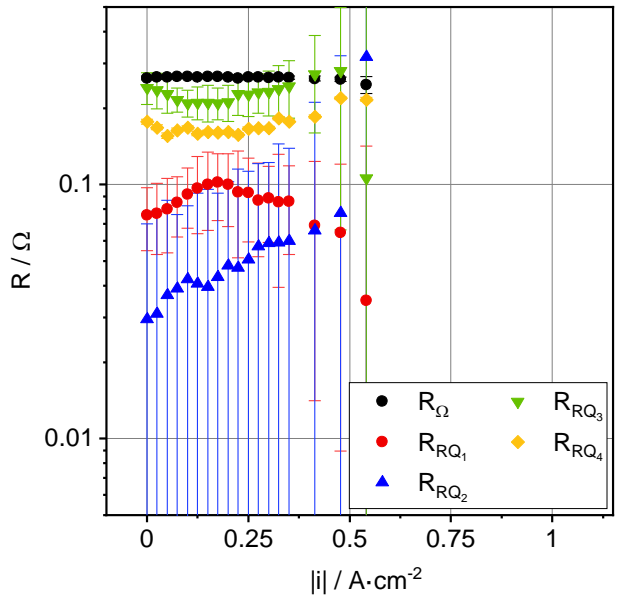

(a)

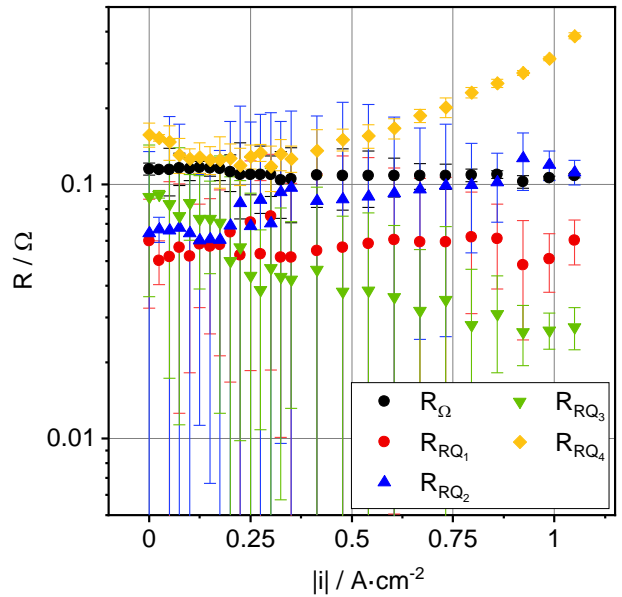

(b)

Figure 7. Resistances with respect to current density for a ratio of $\mathrm{CO}_{2}: \mathrm{CO}$ of $80: 20$ at $6 \mathrm{~L} \cdot \mathrm{h}^{-1}$ at (a) $700{ }^{\circ} \mathrm{C}$ and (b) $900^{\circ} \mathrm{C}$.

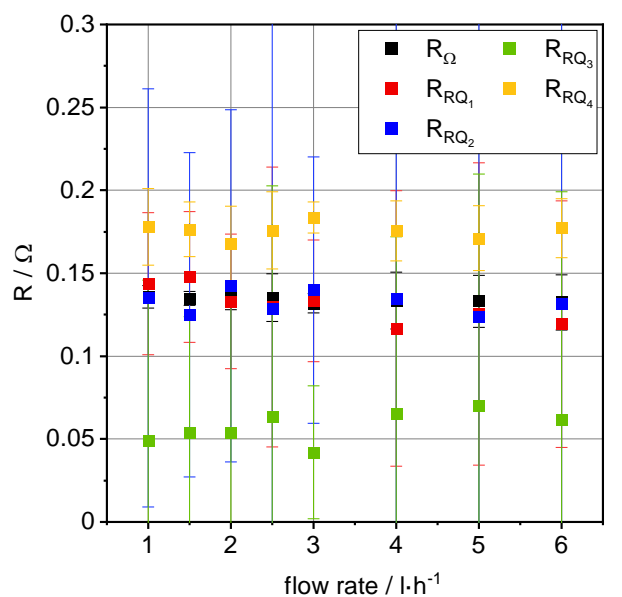

(a)

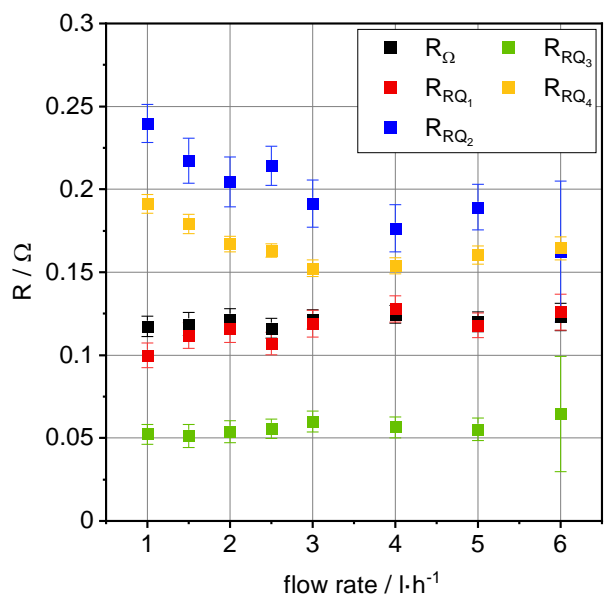

(b)

Figure 8. Resistances with respect to the flow rate for a ratio of $\mathrm{CO}_{2}: \mathrm{CO}$ of $80: 20$ at $800{ }^{\circ} \mathrm{C}$ at (a) $\mathrm{OCV}$ and (b) $0.35 \mathrm{~A} \cdot \mathrm{cm}^{-2}$.

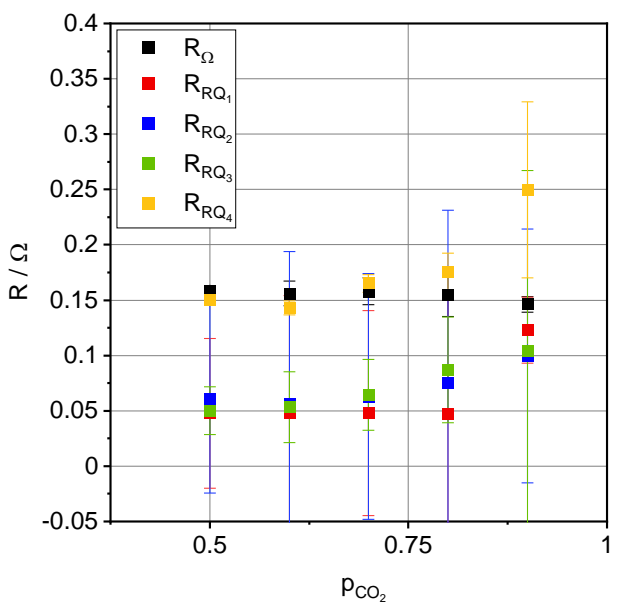

(a)

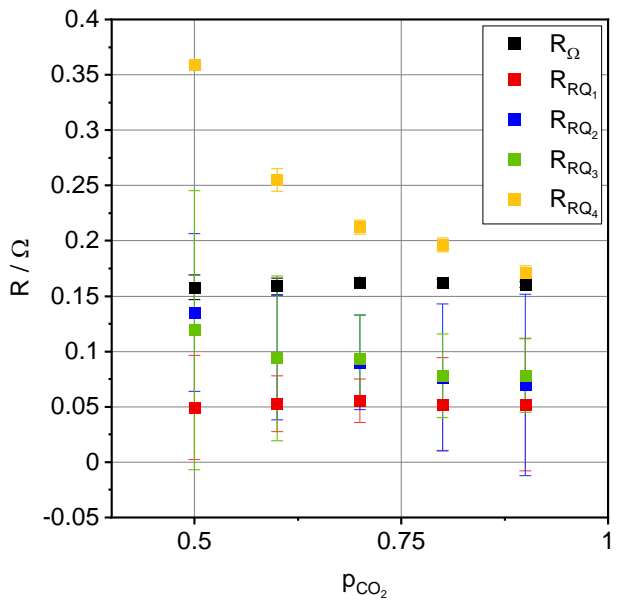

(b)

Figure 9. Resistances with respect to the $\mathrm{CO}_{2}$ partial pressure at $800^{\circ} \mathrm{C}$ and (a) $\mathrm{OCV}$ and (b) $0.35 \mathrm{~A} \cdot \mathrm{cm}^{-2}$. 
The variation of temperature might reveal the most insightful analysis towards the assignment of the RQ element to physical processes. The resistances can be plotted in an Arrhenius diagram $(\ln (\mathrm{R})$ $\rightarrow \mathrm{T}^{-1}$ ) and from the slope the activation energy can be obtained. The Arrhenius plots for a $\mathrm{CO}_{2}: \mathrm{CO}$ ratio of 80:20 are shown in Figure 6 and the respective activation energies in Table 1. For the activation energies the resistances for temperatures above $850{ }^{\circ} \mathrm{C}$ were not considered due to the cell degradation falsifying the results.

Table 1. Activation energies for the resistances $R_{\Omega}$ and $R_{R Q 1}$ to $R_{R Q 4}$ for a ratio of $C O_{2}: C O$ of 80:20.

\begin{tabular}{ccc}
\hline Process & $\mathbf{E}_{\mathbf{a}, \mathbf{O C V}}\left[\mathbf{k J} \cdot \mathbf{m o l}^{\mathbf{- 1}} \mathbf{]}\right.$ & $\mathbf{E}_{\mathbf{a}, \mathbf{0 . 3 5} \mathbf{A} \cdot \mathbf{c m}}{ }^{\mathbf{2}}\left[\mathbf{k J} \cdot \mathbf{m o l}^{\mathbf{- 1}} \mathbf{]}\right.$ \\
\hline $\mathrm{R}_{\Omega}$ & $40.6 \pm 1.5$ & $38.1 \pm 2.0$ \\
$\mathrm{R}_{\mathrm{RQ} 1}$ & $71.8 \pm 5.4$ & $18.5 \pm 3.8$ \\
$\mathrm{R}_{\mathrm{RQ} 2}$ & $36.2 \pm 8.0$ & $80.2 \pm 8.4$ \\
$\mathrm{R}_{\mathrm{RQ} 3}$ & $36.3 \pm 7.3$ & $71.8 \pm 2.4$ \\
$\mathrm{R}_{\mathrm{RQ} 4}$ & $10.0 \pm 2.1$ & $19.1 \pm 3.5$ \\
\hline
\end{tabular}

The obtained activation energies differ hugely comparing OCV and $0.35 \mathrm{~A} \cdot \mathrm{cm}^{-2}$. Only the activation of the ohmic resistance stays the same for increased current density. With ca. $40 \mathrm{~kJ} \cdot \mathrm{mol}^{-1}$ it is only half of the activation energy given in literature [20,21]. There it is compared to the activation energy of ionic conductivity in $8 \mathrm{YSZ}$, given as $88 \mathrm{~kJ} \cdot \mathrm{mol}^{-1}$ [22]. In the cells used in this publication, however, the electrolyte material is significantly thinner than what is used in literature. Since not only the ionic conductivity of 8YSZ but also the ionic and electronic conductivities of the electrodes and wires as well as the conduction across material borders influence the ohmic resistance, a reduced electrolyte thickness increases the contribution of those other parts. This results in lowering the activation energy of the ohmic resistance presented here.

The activation energies for the resistances $R_{R Q 1}, R_{R Q 2}$ and $R_{R Q 3}$ seem to switch in magnitude from OCV to $0.35 \mathrm{~A} \cdot \mathrm{cm}^{-2}$. While the thermal activation of RQ1 is significantly reduced with current, the activation of RQ2 and RQ3 are increased. Values for activation energies of single processes in $\mathrm{CO}_{2}$ electrolysis were up to this time not reported in literature. Li et al. [23] investigated the influence of process parameters including temperature, however, did not show dependencies of single processes. Their obtained activation energy for the polarization resistance of around $60-70 \mathrm{~kJ} \cdot \mathrm{mol}^{-1}$ is larger than what we obtain $\left(29 \mathrm{~kJ} \cdot \mathrm{mol}^{-1}\right)$. It has to be noted though that they measure at different temperatures $\left(600-700{ }^{\circ} \mathrm{C}\right)$ and gas compositions employing different cell types. If only the temperature range of $700-750{ }^{\circ} \mathrm{C}$ is considered the activation energy for our polarization resistance increases to $46 \mathrm{~kJ} \cdot \mathrm{mol}^{-1}$, which is closer to what is reported by Li et al. showing a comparability.

Other literature studies of $\mathrm{CO}_{2}$ electrolysis don't include Arrhenius analyses. Only some studies performed on fuel cell analysis or steam or co-electrolysis report activation energies for separate processes. Reported by modelling studies $[17,24]$ an activation energy of $86.50 \mathrm{~kJ} \cdot \mathrm{mol}^{-1}$ and $86.50 \mathrm{~kJ} \cdot \mathrm{mol}^{-1}$ is given for the surface reaction of adsorbed $\mathrm{CO}_{2}$ to adsorbed $\mathrm{CO}$ and $\mathrm{O}$. This would fit $R_{R Q 1}$ at $\mathrm{OCV}$ or $\mathrm{R}_{\mathrm{RQ2}}$ or $\mathrm{R}_{\mathrm{RQ3}}$ at $0.35 \mathrm{~A} \cdot \mathrm{cm}^{-2}$. As also the current density has a huge impact on $R_{R Q 2}$ (compare Figure 5) it is assumed that this process is connected to the triple-phase boundary reaction. In the fitting procedure it also turned out that $R_{R Q 1}$ and $R_{R Q 2}$ tend to exchange. Leonide/Sonn et al. $[20,25]$ report for fuel cells that the two high-frequency processes are coupled processes including oxygen transport in YSZ of the fuel electrode, charge transfer at the triple phase boundary on the fuel electrode and gas diffusion inside the fuel electrode functional layer.

The process being expressed by $\mathrm{R}_{\mathrm{RQ} 4}$ shows only a low thermal activation. In other experiments of co-electrolysis in our group the activation energy was even lower or showed negative values. Due to the low activation energy it has been assigned to gas diffusion as reported in literature by Primdahl [26], Ebbesen [27] and Leonide [20]. The results presented in this study also show that the activation energy of this process increases with increasing the operating current. This was also observed in other experiments for co-electrolysis in our group. 
The resistance $R_{R Q 4}$ is also strongly influenced by the current density as can be seen in Figure 7 . At low current densities it slightly decreases and then increases almost exponentially with increase current. This behavior is more pronounced at $900{ }^{\circ} \mathrm{C}$ than at $700{ }^{\circ} \mathrm{C}$ and therefore shows a similar trend as the ASR observation from dc measurements. The highly increased resistance at high current densities supports the assignment to a diffusion process as transport limitations become more and more significant with increased current density. Even though the overall reactant utilization is not reaching high values, a local depletion of reactant is possible.

The flow rate is influencing the resistances $R_{R Q 2}$ and $R_{R Q 4}$ under load as can be seen in Figure 8 . Below the flow rate of $3 \mathrm{~L} \cdot \mathrm{h}^{-1}$ both resistances increase. $\mathrm{R}_{\mathrm{RQ} 2}$ has been assigned to a process connected to the reaction on the fuel side, while $\mathrm{R}_{\mathrm{RQ} 4}$ has been assigned to a diffusion process. At increased current more reactant is converted. This reactant amount needs to be transported to the triple phase boundary (TPB) for conversion. Decreasing the flow leading to a decreased mass transport is expected and therefore the increase of $\mathrm{R}_{\mathrm{RQ} 4}$ can be explained. The decreased mass transport, however, also reduces the local reactant concentrations, which then also influences the reaction itself. Thus, the increase of both resistances can be explained if they are connected/coupled. The reaction cannot occur without diffusion preceding it and if diffusion is negatively affected by flow rate, so is the TPB reaction.

The partial pressure dependence reveals an assignment of $R_{R Q 2}, R_{R Q 3}$ and $R_{R Q 4}$ to the fuel electrode (Figure 9). Especially the process RQ4 is influenced by the partial pressure. At OCV the resistance increases with increasing the $\mathrm{CO}_{2}$ partial pressure, while it decreases at $0.35 \mathrm{~A} \cdot \mathrm{cm}^{-2}$. This might be explained by the fact that at OCV the ac signal is in both the fuel cell and electrolysis direction. With increased $\mathrm{CO}_{2}$ partial pressure, the $\mathrm{CO}$ partial pressure is decreased causing the increase in resistance at $\mathrm{OCV}$. The assignment to diffusional processes also applies well, since the low concentrations of $\mathrm{CO}$ then cause local depletion for $\mathrm{CO}$ reduction. There also the trend of $\mathrm{R}_{\mathrm{RQ2}}$ fits in well, as it is similar to that of $\mathrm{R}_{\mathrm{RQ} 4}$ only less pronounced. At $0.35 \mathrm{~A} \cdot \mathrm{cm}^{-2}$ the trend for $\mathrm{R}_{\mathrm{RQ} 4}$ that was expected is observed. Increasing the $\mathrm{CO}_{2}$ partial pressure increases the reactant concentrations and decreasing the diffusion resistance and with it also the resistance $R_{R Q 2}$, which is probably connected to the reaction on the fuel side.

\section{Conclusions}

Taking the increased degradation into account, the optimal operating temperature of a direct carbon dioxide electrolysis on solid oxide cells would be $800-850{ }^{\circ} \mathrm{C}$. The topic of degradation will and has to be addressed in detail in future publications of our group. The highest performance can then be obtained for $80-90 \% \mathrm{CO}_{2}$ balanced with $\mathrm{CO}$. At $1.4 \mathrm{~V}$, also the current density is the highest. However, it is more beneficial to stay at around $1.1 \mathrm{~V}$ as the increased current density above that voltage does not follow a linear increase with voltage. Therefore, the increase in performance comes at a high cost in additionally needed power. The general trend of our outcomes will be observed in on-going and future long-term degradation experiments.

The variation of the feed gas composition $\mathrm{CO}_{2}: \mathrm{CO}$ starting at a ratio of 90:10 with increments of $10 \%$ to $50: 50$ shows the simulated gradient of a gas flow through channels over a larger cell. With these results for operation at load $\left(0.35 \mathrm{~A} \cdot \mathrm{cm}^{-2}\right)$, the lack of a critical drop in performance regarding ASR and polarization resistance indicates, that an operation with both a high starting concentration of $\mathrm{CO}_{2}$ and a high fuel utilization above $40 \%$ is possible. The dominant part of the decrease in performance is identified as the process of diffusion. With a distinct design of gas flux within stacks and system, the possibility of high conversion rates is given even for elevated feeds of $\mathrm{CO}_{2}: \mathrm{CO}$ ratios.

The highest reactant utilization can be reached for low flow rates. With suitable mass flow controllers, lower rates than $1 \mathrm{~L} \cdot \mathrm{h}^{-1}$ are possible and probably increase the utilization even further. These parameters describe superior efficiencies for the electrochemical reaction of $\mathrm{CO}_{2}$ to $\mathrm{CO}$. Our results give an extensive outlook for scaling carbon dioxide electrolysis into stacks and systems. Especially regarding the moderate increase from 0.44 to $0.47 \Omega \cdot \mathrm{cm}^{2}$ of ASR at $0.35 \mathrm{~A} \cdot \mathrm{cm}^{-2}$ with the decrease in flow rate, the fuel utilization is improved significantly resulting in elevated space-time velocities and 
yields. With a suitable chemical engineering of the electrochemical system, desired high fuel utilization combined with low degrading operation conditions are achievable.

Overall, our study explicitly exhibits the electrochemical trends of the variation of all important parameters for the running process of pure $\mathrm{CO}_{2}$-electrolysis. Our work puts a stronger focus on $\mathrm{CO}_{2}$ as a useable base chemical without having water involved in the process. Thereby, it allows the contemplation of electrolysis for the production of carbon monoxide by diversifying from co-electrolysis and pure water electrolysis coupled with water-gas shift reaction. Therefore, the potential of the conversion of carbon dioxide to carbon monoxide via solid oxide electrolysis to be a key enabling technology for the transformation of chemical industry from fossil resources to sustainable sources of carbon is disclosed.

Author Contributions: L.D., S.F. and T.D. conceived and designed the experiments; L.D. and T.D. performed the experiments; L.D., S.F. and T.D. analyzed the data; L.D., S.F. and T.D. wrote the paper, S.F., L.D., I.V., R.-A.E. and L.G.J.d.H. reviewed and edited the manuscript; S.F., I.V. and L.G.J.d.H. supervised the work; R.-A.E. and L.G.J.d.H. were responsible for funding acquisition. All authors have read and agreed to the published version of the manuscript.

Funding: The authors gratefully acknowledge funding by the German Federal Ministry of Education and Research (BMBF) within the Kopernikus Project P2X: Flexible use of renewable resources-research, validation and implementation of 'Power-to- $X$ ' concepts and the iNEW Project: incubator sustainable and renewable value chains.

Conflicts of Interest: The authors declare no conflict of interest. The funders had no role in the design of the study; in the collection, analyses, or interpretation of data; in the writing of the manuscript, or in the decision to publish the results.

\section{Appendix A}

Table A1. ASR, $|i| 1.4 \mathrm{~V}$ and $\mathrm{OCV}$ for various ratios of $\mathrm{CO}_{2}: \mathrm{CO}$ at $800{ }^{\circ} \mathrm{C}$.

\begin{tabular}{|c|c|c|c|c|c|}
\hline $\mathrm{CO}_{2}: \mathrm{CO}$ & $\begin{array}{c}\mathrm{ASR}_{\mathrm{OCV}} \\
{\left[\Omega \cdot \mathrm{cm}^{2}\right]}\end{array}$ & $\begin{array}{c}\mathrm{ASR}_{0.35 \mathrm{~A} \cdot \mathrm{cm}^{-2}} \\
{\left[\Omega \cdot \mathrm{cm}^{2}\right]}\end{array}$ & $\begin{array}{c}|i|_{1.4 \mathrm{~V}} \\
{\left[\mathrm{~A} \cdot \mathrm{cm}^{-2}\right]}\end{array}$ & $\begin{array}{c}\mathrm{OCV}_{\text {exp }} \\
\text { [V] }\end{array}$ & $\begin{array}{c}\mathrm{OCV}_{\text {theo }} \\
{[\mathrm{V}]}\end{array}$ \\
\hline $50: 50$ & 0.34 & $0.67 / 1.05^{1}$ & $0.58 / 0.50^{1}$ & 0.95 & 0.94 \\
\hline $60: 40$ & 0.36 & $0.54 / 0.91^{1}$ & $0.66 / 0.56^{1}$ & 0.93 & 0.93 \\
\hline $70: 30$ & 0.39 & $0.51 / 0.82^{1}$ & $0.74 / 0.66^{1}$ & 0.91 & 0.91 \\
\hline $80: 20$ & 0.43 & $0.46 / 0.70^{1}$ & $0.83 / 0.75^{1}$ & 0.89 & 0.88 \\
\hline $90: 10$ & 0.56 & $0.42 / 0.61^{1}$ & $0.92 / 0.83^{1}$ & 0.85 & 0.84 \\
\hline
\end{tabular}

${ }^{1}$ Two values are given because of the hysteresis. The first denotes the forward scan and the second the backward scan of the iV curve.

Table A2. ASR, $|i| 1.4 \mathrm{~V}$ and OCV for various temperatures for the ratio of $\mathrm{CO}_{2}: \mathrm{CO}$ of 80:20.

\begin{tabular}{cccccc}
\hline $\mathbf{T}\left[{ }^{\circ} \mathbf{C}\right]$ & $\begin{array}{c}\mathbf{A S R}_{\mathbf{O C V}} \\
{\left[\mathbf{\Omega} \cdot \mathbf{c m}^{2}\right]}\end{array}$ & $\begin{array}{c}\mathbf{A S R}_{\mathbf{0 . 3 5} \mathbf{A} \cdot \mathbf{c m}} \\
{\left[\mathbf{\Omega} \cdot \mathbf{c m}^{\mathbf{2}}\right]}\end{array}$ & $\begin{array}{c}|\mathbf{i}|_{\mathbf{1 . 4} \mathbf{~ V}} \\
{\left[\mathbf{A} \cdot \mathbf{c m}^{-2}\right]}\end{array}$ & $\begin{array}{c}\mathbf{O C V}_{\text {exp }} \\
{[\mathbf{V}]}\end{array}$ & $\begin{array}{c}\mathbf{O C V}_{\text {theo }} \\
{[\mathbf{V}]}\end{array}$ \\
\hline 700 & 0.53 & 0.60 & 0.74 & 0.94 & 0.94 \\
717 & 0.47 & 0.51 & 0.85 & 0.93 & 0.93 \\
734 & 0.44 & 0.44 & 0.95 & 0.92 & 0.92 \\
752 & 0.41 & 0.39 & 1.03 & 0.91 & 0.91 \\
771 & 0.41 & 0.39 & $1.07 / 1.03$ & 0.90 & 0.90 \\
791 & 0.37 & 0.35 & $1.14 / 1.07^{1}$ & 0.89 & 0.89 \\
811 & 0.36 & 0.33 & $1.21 / 1.17^{1}$ & 0.88 & 0.88 \\
832 & 0.35 & 0.30 & $1.28 / 1.24^{1}$ & 0.87 & 0.86 \\
853 & 0.33 & 0.30 & 1.32 & 0.86 & 0.85 \\
874 & 0.33 & 0.29 & 1.43 & 0.84 & 0.84 \\
900 & 0.34 & 0.29 & 1.50 & 0.83 & 0.83 \\
\hline
\end{tabular}

${ }^{1}$ Two values are given because of the hysteresis. The first denotes the forward scan and the second the backward scan of the iV curve. 
Table A3. ASR, $|i| 1.4 \mathrm{~V}$ and $\mathrm{OCV}$ for varied flow rate for a $\mathrm{CO}_{2}: \mathrm{CO}$ ratio of $80: 20$ at $800{ }^{\circ} \mathrm{C}$.

\begin{tabular}{|c|c|c|c|c|c|}
\hline $\begin{array}{c}\text { Flow Rate } \\
{\left[1 \cdot h^{-1}\right]}\end{array}$ & $\begin{array}{l}\mathrm{ASR}_{\mathrm{OCV}} \\
{\left[\Omega \cdot \mathrm{cm}^{2}\right]}\end{array}$ & $\begin{array}{c}\mathrm{ASR}_{0.35 \mathrm{~A} \cdot \mathrm{cm}^{-2}} \\
{\left[\Omega \cdot \mathrm{cm}^{2}\right]}\end{array}$ & $\begin{array}{c}|i|_{1.4 \mathrm{~V}} \\
{\left[\mathrm{~A} \cdot \mathrm{cm}^{-2}\right]}\end{array}$ & $\begin{array}{c}\mathrm{OCV}_{\exp } \\
{[\mathrm{V}]}\end{array}$ & $\begin{array}{c}\mathrm{OCV}_{\text {theo }} \\
\text { [V] }\end{array}$ \\
\hline 1.0 & 0.44 & 0.47 & 1.11 & $0.87 / 0.90^{1}$ & 0.88 \\
\hline 1.5 & 0.44 & 0.46 & 1.12 & $0.87 / 0.89^{1}$ & 0.88 \\
\hline 2.0 & 0.43 & 0.46 & 1.14 & $0.87 / 0.89^{1}$ & 0.88 \\
\hline 2.5 & 0.42 & 0.46 & 1.17 & $0.87 / 0.88^{1}$ & 0.88 \\
\hline 3.0 & 0.43 & 0.45 & 1.19 & $0.87 / 0.88^{1}$ & 0.88 \\
\hline 4.0 & 0.42 & 0.44 & 1.22 & $0.87 / 0.87^{1}$ & 0.88 \\
\hline 5.0 & 0.42 & 0.44 & 1.23 & $0.87 / 0.87^{1}$ & 0.88 \\
\hline 6.0 & 0.42 & 0.44 & 1.25 & $0.87 / 0.87^{1}$ & 0.88 \\
\hline
\end{tabular}

1 Two values are given because of the hysteresis. The first denotes the forward scan and the second the backward scan of the iV curve.

\section{References}

1. Foit, S.R.; Dittrich, L.; Theuer, T.; Morgenthaler, S.; Eichel, R.-A.; de Haart, L.G.J. White Syngas by Co-Electrolysis for Industrial Chemistry. ECS Trans. 2019, 91, 2467-2474. [CrossRef]

2. Dittrich, L.; Nohl, M.; Jaekel, E.E.; Foit, S.; de Haart, L.G.J.; Eichel, R.-A. High-Temperature Co-Electrolysis: A Versatile Method to Sustainably Produce Tailored Syngas Compositions. J. Electrochem. Soc. 2019, 166, F971-F975. [CrossRef]

3. Theuer, T.; Schäfer, D.; Dittrich, L.; Nohl, M.; Foit, S.; Blum, L.; Eichel, R.-A.; de Haart, L.G.J. Sustainable Syngas Production by High-Temperature Co-electrolysis. Chem. Ing. Tech. 2020, 92, 40-44. [CrossRef]

4. Haas, T.; Krause, R.; Weber, R.; Demler, M.; Schmid, G. Technical photosynthesis involving $\mathrm{CO}_{2}$ electrolysis and fermentation. Nat. Catal. 2018, 1, 32-39. [CrossRef]

5. Dittrich, L.; Nohl, M.; Theuer, T.; Foit, S.; Vinke, I.C.; de Haart, L.G.J.; Eichel, R.-A. Co-electrolysis-A sustainable technology for syngas production. Chem. Ing. Tech. 2018, 90, 1158-1159. [CrossRef]

6. Foit, S.R.; Vinke, I.C.; de Haart, L.G.J.; Eichel, R.-A. Power-to-Syngas: An Enabling Technology for the Transition of the Energy System? Angew. Chem. Int. Ed. 2017, 56, 5402-5411. [CrossRef]

7. Foit, S.R.; Dittrich, L.; Vibhu, V.; Vinke, I.C.; Eichel, R.-A.; de Haart, L.G.J. Co-Electrolysis, Quo Vadis? ECS Trans. 2017, 78, 3139-3147. [CrossRef]

8. van Bavel, S.; Verma, S.; Negro, E.; Bracht, M. Integrating $\mathrm{CO}_{2}$ Electrolysis into the Gas-to-Liquids-Power-to-Liquids Process. ACS Energy Lett. 2020, 5, 2597-2601. [CrossRef]

9. Küngas, R. Review-electrochemical $\mathrm{CO}_{2}$ reduction for $\mathrm{CO}$ production: Comparison of low- and high-temperature electrolysis technologies. J. Electrochem. Soc. 2020, 167, 044508. [CrossRef]

10. Zhan, Z.; Zhao, L. Electrochemical reduction of $\mathrm{CO}_{2}$ in solid oxide electrolysis cells. J. Power Sources 2010, 195, 7250-7254. [CrossRef]

11. Song, Y.; Zhang, X.; Xie, K.; Wang, G.; Bao, X. High-temperature $\mathrm{CO}_{2}$ electrolysis in solid oxide electrolysis cells: Developments, challenges, and prospects. Adv. Mater. 2019, 31, 1902033. [CrossRef]

12. Song, Y.; Zhou, Z.; Zhang, X.; Zhou, Y.; Gong, H.; Lv, H.; Liu, Q.; Wang, G.; Bao, X. Pure $\mathrm{CO}_{2}$ electrolysis over an Ni/YSZ cathode in a solid oxide electrolysis cell. J. Mater. Chem. A 2018, 6, 13661-13667. [CrossRef]

13. Skafte, T.L.; Blennow, P.; Hjelm, J.; Graves, C. Carbon deposition and sulfur poisoning during $\mathrm{CO}_{2}$ electrolysis in nickel-based solid oxide cell electrodes. J. Power Sources 2018, 373, 54-60. [CrossRef]

14. Zhang, X.; Song, Y.; Wang, G.; Bao, X. Co-electrolysis of $\mathrm{CO}_{2}$ and $\mathrm{H}_{2} \mathrm{O}$ in high-temperature solid oxide electrolysis cells: Recent advance in cathodes. J. Energy Chem. 2017, 26, 839-853. [CrossRef]

15. Liu, T.; Chen, X.; Wu, J.; Sheng, Z.; Liu, G.; Wang, Y. A highly-performed, dual-layered cathode supported solid oxide electrolysis cell for efficient $\mathrm{CO}_{2}$ electrolysis fabricated by phase inversion co-tape casting method. J. Electrochem. Soc. 2017, 164, F1130-F1135. [CrossRef]

16. Xu, S.; Li, S.; Yao, W.; Dong, D.; Xie, K. Direct electrolysis of $\mathrm{CO}_{2}$ using an oxygen-ion conducting solid oxide electrolyzer based on $\mathrm{La}_{0.75} \mathrm{Sr}_{0.25} \mathrm{Cr}_{0.5} \mathrm{Mn}_{0.5} \mathrm{O}_{3-\delta}$ electrode. J. Power Sources 2013, 230, 115-121. [CrossRef] 
17. Shi, Y.; Luo, Y.; Cai, N.; Qian, J.; Wang, S.; Li, W.; Wang, H. Experimental characterization and modeling of the electrochemical reduction of $\mathrm{CO}_{2}$ in solid oxide electrolysis cells. Electrochim. Acta 2013, 88, 644-653. [CrossRef]

18. Bidrawn, F.; Kim, G.; Corre, G.; Irvine, J.T.S.; Vohs, J.M.; Gorte, R.J. Efficient reduction of $\mathrm{CO}_{2}$ in a solid oxide electrolyzer. Electrochem. Solid-State Lett. 2008, 11, B167. [CrossRef]

19. Udomsilp, D.; Roehrens, D.; Menzler, N.H.; Bischof, C.; de Haart, L.G.J.; Opitz, A.K.; Guillon, O.; Bram, M. High-performance metal-supported solid oxide fuel cells by advanced cathode processing. J. Electrochem. Soc. 2017, 164, F1375-F1384. [CrossRef]

20. Leonide, A.; Sonn, V.; Weber, A.; Ivers-Tiffée, E. Evaluation and modeling of the cell resistance in anode-supported solid oxide fuel cells. J. Electrochem. Soc. 2008, 155, B36. [CrossRef]

21. Korte, C.; Peters, A.; Janek, J.; Hesse, D.; Zakharov, N. Ionic conductivity and activation energy for oxygen ion transport in superlattices-the semicoherent multilayer system $\mathrm{YSZ}\left(\mathrm{ZrO}_{2}+9.5 \mathrm{~mol} \% \mathrm{Y}_{2} \mathrm{O}_{3}\right) / \mathrm{Y}_{2} \mathrm{O}_{3}$. Phys. Chem. Chem. Phys. 2008, 10, 4623-4635. [CrossRef]

22. Badwal, S.P.S. Zirconia-based solid electrolytes: Microstructure, stability and ionic conductivity. Solid State Ionics 1992, 52, 23-32. [CrossRef]

23. Li, W.; Shi, Y.; Luo, Y.; Wang, Y.; Cai, N. Carbon monoxide/carbon dioxide electrochemical conversion on patterned nickel electrodes operating in fuel cell and electrolysis cell modes. Int. J. Hydrogen Energy 2016, 41, 3762-3773. [CrossRef]

24. Hecht, E.S.; Gupta, G.K.; Zhu, H.; Dean, A.M.; Kee, R.J.; Maier, L.; Deutschmann, O. Methane reforming kinetics within a Ni-YSZ SOFC anode support. Appl. Catal. A Gen. 2005, 295, 40-51. [CrossRef]

25. Sonn, V.; Leonide, A.; Ivers-Tiffée, E. Combined deconvolution and CNLS fitting approach applied on the impedance response of technical Ni/8YSZ cermet electrodes. J. Electrochem. Soc. 2008, 155, B675. [CrossRef]

26. Primdahl, S.; Mogensen, M. Gas diffusion impedance in characterization of solid oxide fuel cell anodes. J. Electrochem. Soc. 1999, 146, 2827-2833. [CrossRef]

27. Ebbesen, S.D.; Sun, X.; Mogensen, M.B. Understanding the processes governing performance and durability of solid oxide electrolysis cells. Faraday Discuss. 2015, 182, 393-422. [CrossRef] [PubMed]

Publisher's Note: MDPI stays neutral with regard to jurisdictional claims in published maps and institutional affiliations.

(C) 2020 by the authors. Licensee MDPI, Basel, Switzerland. This article is an open access article distributed under the terms and conditions of the Creative Commons Attribution (CC BY) license (http://creativecommons.org/licenses/by/4.0/). 